\title{
THE NORTH ATLANTIC OSCILLATION AND WINTER PRECIPITATION TOTALS IN SLOVAKIA
}

\author{
Lívia LABUDOVÁ, Pavel ŠŤASTNÝ, Milan TRIZNA
}

\begin{abstract}
The North Atlantic Oscillation (NAO) is the most important circulation phenomenon in the Northern Atlantic which impacts climate in Europe in various ways. Precipitation is a basic climatic element which affects the landscape significantly. Therefore in this paper, the relationship between the NAO and winter precipitation in Slovakia is analysed. A Spearman's correlation analysis was used, which detected the impacts of NAO on the above-mentioned seasonal precipitation in different regions of Slovakia. The correlation coefficients obtained positive values in the region of Orava and Kysuce and changed to negative ones in a southward direction. The detected zonal configuration can be explained by the topographic barrier effect of the Carpathians.
\end{abstract}

\section{Shrnutí}

\section{Vztah Severoatlantické oscilace a zimních úhrnů srážek na Slovensku}

Severoatlantická oscilace (NAO) je nejvýznamnějším cirkulačním jevem na severní polokouli, která ovlivňuje klima Evropy v různých směrech. Srážky jsou základním klimatickým prvkem, který významně ovlivňuje krajinu. Proto je v tomto př́spěvku analyzován vztah mezi NAO a zimními úhrny srážek na Slovensku. Byla použita Spearmanova korelační metoda, která zjistila protikladné vlivy NAO na již zmiňované sezonní srážkové úhrny. Zatímco kladné korelační koeficienty byly dosažené v oblasti Oravy a Kysuc, směrem $k$ jihu se korelace měnila na negativní. Zjištěná zonální stratifikace může být vysvětlena bariérovým efektem Karpat.

Key words: North Atlantic Oscillation, winter precipitation totals, precipitation regions, Spearman's correlation analysis, Slovakia

\section{Introduction}

The North Atlantic Oscillation (NAO) is one of the most important modes of atmospheric circulation, which affects significantly climate variability not only in Europe, but in the whole area from the eastern coast of USA to Siberia in a latitudinal direction, and from the Arctic to subtropical Atlantic in a meridional direction (Hurrell, 1996; Hurrell et al., 2003). In Europe, the strongest impacts of oscillation on the air temperature and precipitation regimes are detected in Scandinavia, in the British Isles and in the Mediterranean region, where impacts have different effects (Doležalová, 2007). The assessment of the relation between NAO and climatic elements is of interest in Slovakia, because of its location between the above-mentioned regions. Precipitation is one of the basic climatological elements, which affects the landscape significantly. Pekárová et al. (2010) published an analysis of the relationship between the $\mathrm{NAO}$ and the long-term discharge of Slovak rivers. It was recorded that the influence of the NAO on the discharge of lowland rivers is stronger than on the discharge of the rivers in northern mountainous part of Slovakia. Considering that precipitation is the main input element into the river catchments and forms a discharge, it is interesting to identify the relationship between the NAO and precipitation. The impact of the oscillation is much smaller in summer than in winter. Therefore, the main focus here is on the assessment of the impact of the North Atlantic Oscillation on the winter precipitation totals in Slovakia.

\section{The Concept of the North Atlantic Oscillation}

The phenomenon of the North Atlantic Oscillation is based on the existence of a pressure gradient between the Azores high and Icelandic low, which are stable semi-permanent pressure systems (as the Azores high moves northwards during summer). They are located almost in one line in a meridional direction in the northern Atlantic. The earlier-mentioned pressure gradient is caused by such a pattern of pressure fields 
and determines the strength of westerlies in this region. Westerlies are controlled by the direction of rotation in pressure systems which is caused by the Coriolis force, i.e. in the Azores high clockwise and in the Icelandic low counterclockwise (Fig. 1). The periodic variability of the strength and the position of these semi-permanent pressure systems (Ahrens, 2007; Oliver, 2008) is a natural source of climate variability in the affected area (Barnston, Livezey, 1987; Hurrell et al., 2003; Lamb, Peppler, 1987).

The direction of the westerlies coincides with the direction of storm tracks. If the air pressure is abovenormal over the Azores and below-normal across the Iceland area, the gradient between the Azores high and Icelandic low is higher than normal, the westerlies are enhanced and the meridional flow is weakened. In this case, there is a positive phase of oscillation. During the opposite situation, the gradient between them is lower and conditions for enhanced meridional flow are more favourable (Hurrell, 2003). This situation is demonstrated in wintertime by an influx of very cold arctic air into middle latitudes, which is caused by 'leaking' Rossby waves during weakened Arctic Oscillation.

The North Atlantic Oscillation is one of the most prominent teleconnection patterns, because parallel climate variability with different effects over large geographical regions is caused by its activity. This means that some regions appear colder and dryer, while other regions hundreds of kilometres away appear warmer and wetter than during normal conditions (Oliver, 2008).

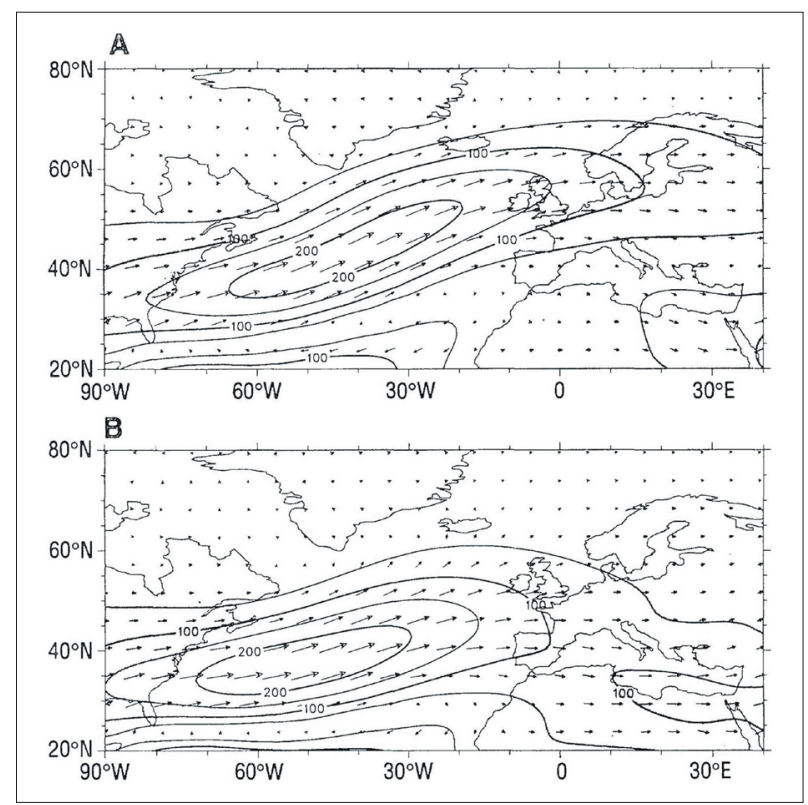

Fig. 1: Vectors of the vertically integrated moisture transports for high NAO index winters (A) and normal or low NAO index winters $(B)$

Source: Hurrell, 1995
The positive oscillation phase also causes the storm tracks to prevail in a northward direction to Scandinavia. Over Scandinavia, there is the strongest positive oscillation influence, as well as in the British Isles. During this phase, westerlies bring more relatively warmer and wetter air from the ocean into the European continent. It causes milder and wetter winters, especially in the western and northern parts of Europe, but also a plunging of very cold air over the northwestern Atlantic. This phase is demonstrated by lower sea level temperatures and a larger extent of the sea ice cover near the Labrador Peninsula (Fig. 2). The different effects of cooling and drying are marked in the Mediterranean, Northern Africa and Middle East. During the negative phase, the stormtracks move towards the Mediterranean region, where higher air temperature and precipitation totals are recorded during this phase. On the other hand, the precipitation totals are below-normal in Scandinavia and in the British Isles (Hurrell, 1995; Hurrell, 2001; Barry, Chorley, 2003; Doležalová, 2007; Beranová, Huth, 2008). The temperatures in Central Europe correlate positively with the NAO phases, but there is a more complicated relation between the NAO and precipitation totals (see below). Within this relation, a theoretical borderline between positive and negative correlation coefficients could be placed in the Alpine and Carpathian regions.

The phases of the North Atlantic Oscillation are characterized by the NAO Indices. There are several indices, which use different data sources. Some of them are based on the difference of normalized sea level pressure between two stations near the Azores and Iceland (e.g Lisbon, Portugal and Stykkisholmur/ Reykjavik, Iceland). The sea level pressure values at each station are normalized by removing the longterm mean and consequently by dividing by the longterm standard deviation (Hurrell, 1996; Hurrell, 2011; Hurrell, 2013). The long-term means and long-term standard deviations were extracted from data in the period 1864-1983.

$$
\mathrm{p}_{\mathrm{N}}=\mathrm{p} / \overline{\sigma_{\overline{\mathrm{p}}}}
$$

$\mathrm{p}_{\mathrm{N}}-$ normalized sea level pressure,

p - seasonal mean sea level pressure,

$\overline{\sigma_{\bar{p}}}-$ long-term mean standard deviation.

\section{Previous analyses of relationships between the NAO and precipitation in Europe}

Correlation and spectral analyses are often used for the assessment of NAO effects. Several studies have been carried out to analyse the impact of the North 


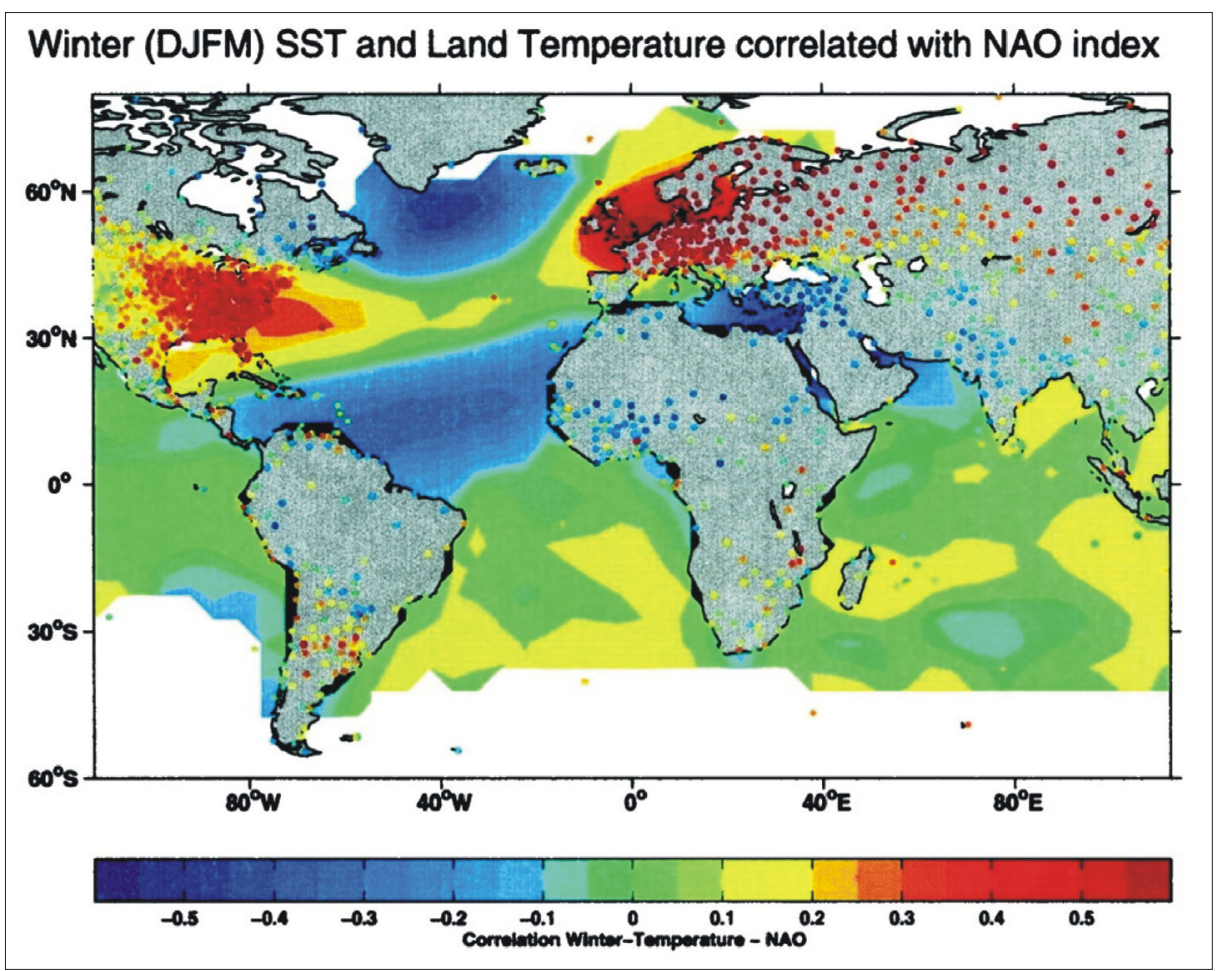

Fig. 2: Correlation coefficients between the average winter temperature and the Hurrell Oscillation Index during the positive NAO phase (Source: Visbeck et al., 2001)

Atlantic Oscillation on precipitation totals in Europe. Europe as a whole was assessed by Hurrell (1995), Osborn et al. (1999), Beranová, Huth (2008), inter alia. The last-mentioned authors employed Pearson correlation coefficients to evaluate the relation between the oscillation, the mean air temperature and the precipitation totals in winter in the period from 1958 to 1998 . Using a 15-year moving window, they eliminated the low-frequency variability, and focused on the fact that the relationship between the NAO and precipitation is not stable over time. The results for the whole period indicate that the correlation between the NAO index and the maximum air temperature in Europe is positive (maximum +0.73 in Copenhagen), except for the most northwestern ( -0.28 , Iceland) and southeastern (Greece) European stations. The spatial distribution of the NAO impact on precipitation totals was different. The correlation coefficients varied from - 0.62 in Lisbon (Portuguese) and Badajoz (Spain), to +0.69 in Eskdalemuir (Scotland). No significant correlations were found in Eastern and Central Europe, Greece and Valencia (Spain). A cluster analysis of the 15-year moving correlation window identified three clusters, which were basically oriented in a zonal direction. The first cluster with decreasing correlation during the whole period, consists of stations located in the southern parts of Europe. In the second cluster, the stations in the UK, Western, Central and Eastern Europe are included. The correlation trend in this cluster was decreasing until 1975. In the period from 1975 to the end of the study period, however, an increasing trend was observed. The third cluster consists of stations with an increasing trend during the whole period, which are located in Northern Europe. Statistically significant results were identified only for the second cluster.

Osborn et al. (1999) tested the output data of the integrated coupled model HadCM2. Precipitation totals and also deviations from normal values were taken into consideration. The strongest drying effect was found over the Iberian Peninsula, but the analysis of deviations from normal identified more drying in Algeria. The results showed that the data from the integrated coupled model could reproduce quite good conditions obtained from measured station data. Therefore, it is required to use the output data from the model in further modelbased experiments to identify the driving mechanism of low-frequency variability of the oscillation.

Many studies have been carried out on a regional scale, especially in the regions which have the highest correlation between the NAO indexes and climatic elements in previous studies. The first such region is Portugual, Spain and northwestern Africa. Relations between the North Atlantic Oscillation and precipitation, but also between the NAO and the discharge of three international rivers (Douro, Tajo and Guardiana) in the Iberian Peninsula were analysed by Trigo et al. (2004). The strongest influence of the oscillation on discharge in Europe was recorded in this area, and the relation is strongest with a one-month 
shift (the correlation of the discharge in the JanuaryMarch period with the NAO index in the DecemberFebruary period, is higher than the correlation of the discharge and the NAO index in the months DecemberFebruary). This finding can be used for early extreme discharge prediction in these river basins.

This study led to further research in which the relation between the NAO and landslides near Lisbon was examined (Trigo et al., 2005). The results showed that the winter precipitation during the negative NAO phase $(619 \mathrm{~mm})$ is almost two times higher than the precipitation during the positive phase $(339 \mathrm{~mm})$. The negative phase is responsible for long-lasting precipitation episodes, which caused the largest landslides in the studied area in the past. In Spain, regional analysis of the relationship between the NAO and winter precipitation was made by Queralt et al. (2009). The analysis found the highest negative correlation in January along the northwestern Spanish coast (Galicia; correlation coefficient $=-0.83$ ). The correlation decreases eastward and the lowest values are reached on the east coast near Valencia. These results coincide with the study by Gimeno et al. (2005), which pointed out the value of the main precipitation period in Galicia (8.4 years), which is very close to value of the main NAO period (8.3 years).

Morocco also belongs to the region with negative correlation of the NAO and precipitation, especially the most northern coastal area of this country with a correlation coefficient equal to -0.64 (Lamb, Peppler, 1987). The seasonal correlation coefficients were also evaluated for northwestern Italy in the period 1952-2002 (Ciccarelli et al., 2008). A negative correlation $(-0.31)$ between the NAO and precipitation was identified in winter and no significant correlation was found in other seasons.

Different impacts of the oscillation on the precipitation totals were detected in the United Kingdom and Ireland (Murphy, Washington, 2001). The impact is significant from September to April, when the correlation coefficients increase from southeast to northwest with a maximum in the Hebrides and Shetland Islands. A similar study was also carried out for southwestern Norway and southern Spain/northern Morocco, as the most influenced regions by the North Atlantic Oscillation (Matti et al., 2009). These authors used reconstructed data of precipitation for the period $1500-2000$ to evaluate a 30-year moving Spearman's correlation. The correlation in southwestern Norway is most of the time positive and from 1780 also mostly significant. A different situation can be found in southern Spain/ northern Morocco, where the correlation is mainly negative and significant from 1720 (the exception is a small interruption around 1770). During the last decades of the $20^{\text {th }}$ century, a positive NAO phase prevailed, which can be partly explained by the negative trend of the Mediterranean winter precipitation as well as the positive trend of winter precipitation in southwestern Norway.

A strong dependence of precipitation on the NAO is presented by Cherry et al. (2000), using the example of the relation between the $\mathrm{NAO}$ and electricity production by hydropower stations in Norway. On the other hand, the location of Iceland close to the northern action centre of the NAO, causes the correlation of the NAO Index and precipitation in Iceland and its significance to vary in space. A significant positive correlation $(+0.51)$ was recorded only in the northeastern part of the territory. Higher and significant correlations were recorded with Arctic Oscillation (AO) for all parts of the country (Jónsdóttir, Uvo, 2009).

Several studies have been reported for Central Europe. Precipitation data from the seven oldest climatological stations in Central Europe from 1851 to 2007 were analysed by Niedzwiedz et al. (2009). Relevant correlations could only be found for the data from Budapest. The oldest Slovak station - Hurbanovo was not considered in this research. Studies carried out in the Czech Republic indicate much less influence of the North Atlantic Oscillation on precipitation than on air temperature. This influence also varies in space, with no significant impact in the region of Bohemia, but with the negative correlation in the region of Moravia and Silesia (Doležalová, 2007). A relatively low influence of the NAO on the precipitation in Bohemia was confirmed by Bodri et al. (2005). The results of Brázdil et al. (2009) and Brázdil et al. (2012) are in accordance with these previous studies. The authors identified a low correlation $(+0.32)$ between precipitation in the Czech Republic and the NAO Index. Although it is statistically significant, this relationship can only explain $10 \%$ of the precipitation variability in this area (Brázdil et al., 2009), such that any reflection of the NAO in precipitation variability is very limited. The same conclusions were made on the basis of correlation analyses of long-term precipitation data of 12 meteorological stations in the Czech Republic: statistically significant results were identified for only a few stations, while insignificant correlations prevailed (Brázdil et al., 2012). On the other hand, the correlation between the NAO Index and the number of days with snow is strongly negative (January: - 0.70, winter: - 0.64) (Brázdil et al., 2009).

Similar results were published by Bednorz (2004) for Eastern Europe. He assessed the correlation between the Hurrell NAO Index and days with snow 
cover. In early autumn, a negative correlation was detected only in northwest Russia. In November, the correlation line of $-0.5(p \geq 0.99)$ moved westward. The strongest correlation coefficient $(-0.7)$ was observed in January and February in the west of the study area. Similar results were published by Twardosz et al. (2011). They evaluated the correlation coefficients between the amount of liquid and solid (snow) precipitation and the NAO, as well as between the NAO and the number of days with liquid and solid precipitation. The NAO has a significant impact on both the number of days and the total amount of rainand snow-fall in winter. The increasing NAO was reflected in the increase of the number of days with rainfall (January: +0.52 ) and the total amount of rainfall (January: +0.39 ), while the number of days with snowfall (January: -0.50 ) and the total amount of snowfall (January: - 0.45) decreased.

Casty et al. (2005) used a reconstructed data series of temperature and precipitation in the Alpine region (since 1500) to assess the relationship between these climatic elements and the NAO. A 31-year moving correlation was used in their research. The correlation coefficients indicate that the Alpine winter precipitation correlates negatively with the North Atlantic Oscillation. However, this relationship was not stable in time and was not always statistically significant during this period. According to the authors, the instability of this relation can be caused by the location of the Alps on the band of varying influence of the NAO and other atmospheric circulation modes, which controlled Alpine precipitation variability during the recent past. Negative correlations between the NAO Index and precipitation were identified in
Hungary. The relationship is stronger in autumn and winter than in other seasons (Domonkos, Tar, 2003). According to these researchers, this relation can be caused by the fact that a large portion of winter precipitation in Hungary falls from Mediterranean or quasi-Mediterranean cyclones. Weather fronts of northern-tracked cyclones contribute only a small part of the precipitation in Hungary because of the special orographical conditions. This effect was reflected in the significant decrease of winter precipitation in Hungary during the last decades of the $20^{\text {th }}$ century, when the NAO Index had an increasing tendency and the frequency of Genoa cyclones, which have an important effect on weather in Hungary, substantially declined.

\section{Data and Methods}

The monthly precipitation totals from 202 rain gauge stations in Slovakia from 1901 to 2010 were used as the main data base (Fig. 3). The dataset of the precipitation sums was obtained from Šamaj, Valovič (1982) till 1980, and then continued from the DB system of the Slovak Hydrometeorological Institute (SHMI). In the case of missing values, the dataset was completed according to a spatial analysis of the monthly precipitation field in a given month, taking into account neighbouring stations (completion of the data set by SHMI).

The data were analysed at two resolution levels: at the level of the individual rain gauge stations, but also at the generalised level of the precipitation regions. More exactly, the generalised level consists of nine precipitation regions distinguished on the base of precipitation regime, which is characteristic for every individual region (Fig. 3, Tab. 1).

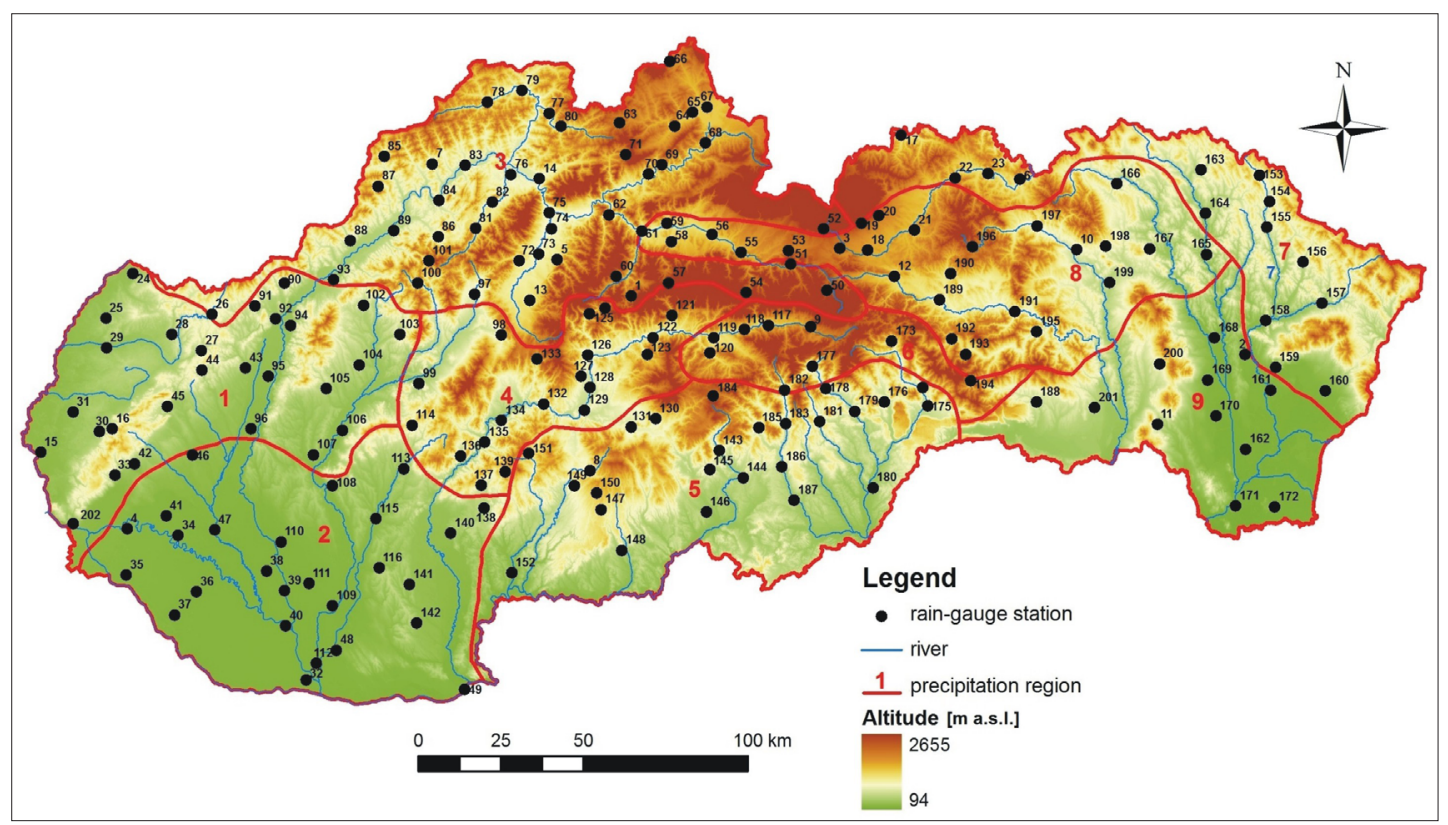

Fig. 3: The location of the rain-gauge stations within the precipitation regions 


\begin{tabular}{|c|l|}
\hline Region & \multicolumn{1}{c|}{ Description of region } \\
\hline region 1 & $\begin{array}{l}\text { transition region between two-peak and one-peak annual precipitation regime with } \\
\text { regular occurrence of rainstorms in summer }\end{array}$ \\
\hline region 2 & $\begin{array}{l}\text { region with one main and one secondary maximum in annual precipitation regime } \\
\text { and with precipitation deficit in a part of summer }\end{array}$ \\
\hline region 3 & region with simple annual precipitation regime with maximum in summer \\
\hline region 4 & $\begin{array}{l}\text { region with one main and one secondary maximum in annual precipitation regime } \\
\text { and with occurrence of rainstorms in summer }\end{array}$ \\
\hline region 5 & $\begin{array}{l}\text { region with sharp two-peak annual precipitation regime and with occurrence of } \\
\text { rainstorms in summer }\end{array}$ \\
\hline region 6 & $\begin{array}{l}\text { transition region between two-peak and one-peak annual precipitation regime with } \\
\text { a precipitation decrease in winter under the influence of continentality }\end{array}$ \\
\hline region 7 & region with simple annual precipitation regime with sharp peak in summer \\
\hline region 8 & region with high contrast between summer and winter precipitation \\
\hline region 9 & $\begin{array}{l}\text { region with simple annual precipitation regime with sharp peak in summer and } \\
\text { possible precipitation deficit in winter under the influence of continentality }\end{array}$ \\
\hline
\end{tabular}

Tab. 1: Precipitation regions in Slovakia

From oscillation indexes, the Hurrell winter oscillation index (NAOI-H), defined by Hurrell in 1995, was selected. It is the station-based index, based on the difference of normalised sea-level pressure at two reference stations: Lisbon (Portugual, $39^{\circ} \mathrm{N}, 9^{\circ} \mathrm{W}$ ), and Stykkisholmur (Iceland, $65^{\circ} \mathrm{N}, 23^{\circ} \mathrm{W}$ ). The time series of NAOI-H is available for every winter period (December-March) since 1864. Data are available at the website of the National Center for Atmospheric Research, Boulder, USA (Hurrell, 2012), and they are regularly updated.

The seasonal (winter: December-March according to the Hurrell winter NAO Index) precipitation totals for individual stations in Slovakia were calculated from monthly sums. These data were the basis for the first, more exact resolution level of the assessment. The normality of the data series was tested using the Lilliefors (Kolmogorov-Smirnov) normality test. Not all stations had a normal distribution of the seasonal precipitation; therefore Spearman's rank correlation method was used for further analysis. Then, the statistical significance of correlation with a significance level $\alpha=0.05$ at both spatial resolution levels was tested with a T-test (Sachs, Hedderich, 1972). The critical value for the correlation is \pm 0.187 for the p-value 0.05 (two-tailed), with sample size $=110$.

For the visualisation of the results on this resolution level, it was necessary to select an appropriate interpolation method considering the use of 3-D interpolation. This method would be correct in the case of dependence between correlation coefficients and altitude. Such dependence was not confirmed (Fig. 4), however, as the resulting coefficient of determination $\left(\mathrm{R}^{2}\right)$ was only 0.161 . In the next step, a 2-D interpolation method was selected and the module v.surf.rst of the program GRASS was used. Considering the density of the station network that was used, it was confirmed that the interpolation results correspond well to our conception of the geographical impacts on the precipitation distribution in Slovakia.

For the generalized level, the seasonal precipitation totals for every precipitation region were calculated. In the next step, rain gauge stations were divided into nine groups in accordance with nine precipitation regions. Then average regional winter precipitation totals were calculated and used as basis for the estimation of the long-term Spearman's rank correlation coefficients between the Hurrell winter oscillation index and the winter precipitation totals. All regression analyses were carried out in the statistical environment R (v. 2.13.1).

\section{Results}

Analyses of the relation between the North Atlantic Oscillation and the precipitation totals in winter showed the impact of the NAO on a seasonal sum of this climatological variable. A zonal configuration of the correlation coefficient with lower values in the northern part and higher values in the southern part of Slovakia, was identified at a generalized resolution level (Fig. 5).

Figure 5 shows that more precipitation is brought into the region of Orava and Kysuce (region 3) during the positive oscillation phase, even though 


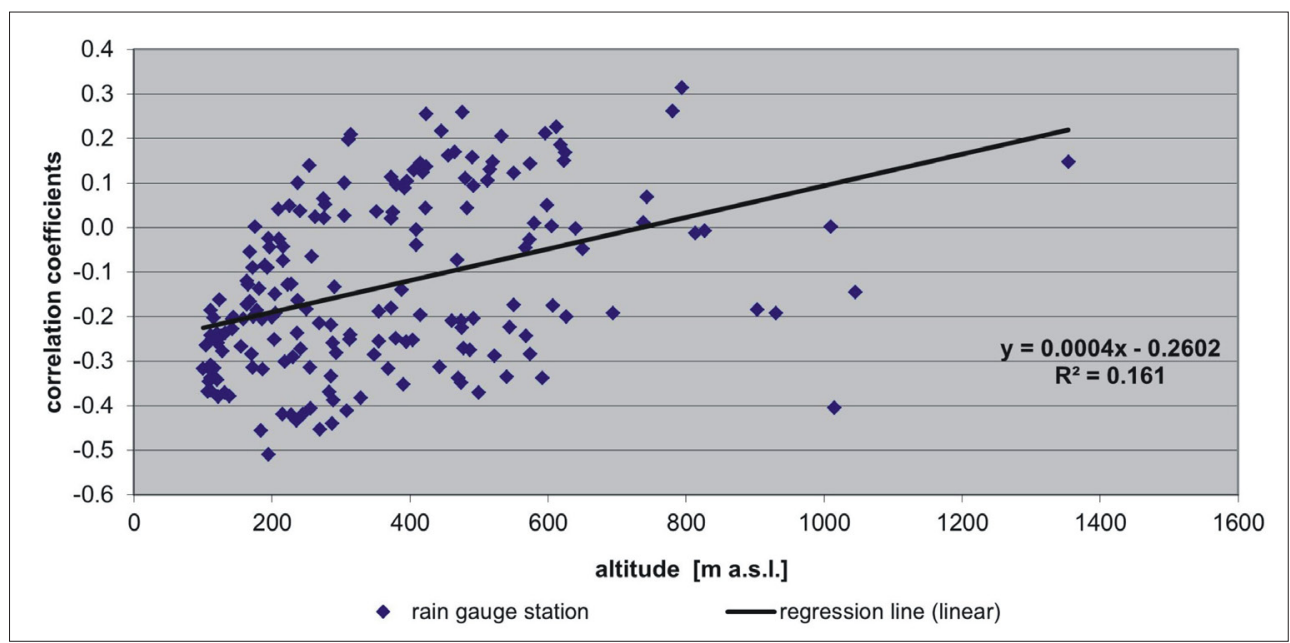

Fig. 4: Dependence of correlation coefficients between Hurrell winter oscillation index and winter precipitation on altitude

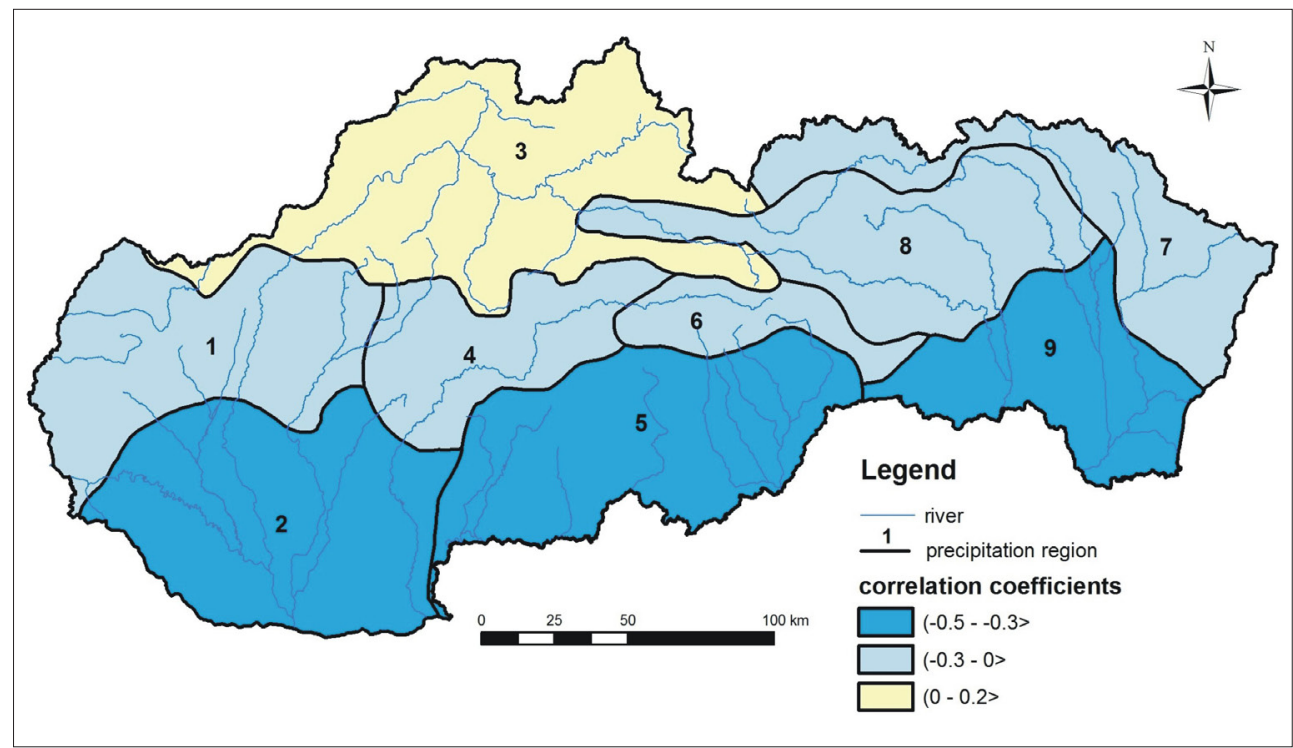

Fig. 5: Correlation coefficients between winter precipitation totals and Hurrell winter oscillation index for individual precipitation regions in Slovakia in period 1901-2010

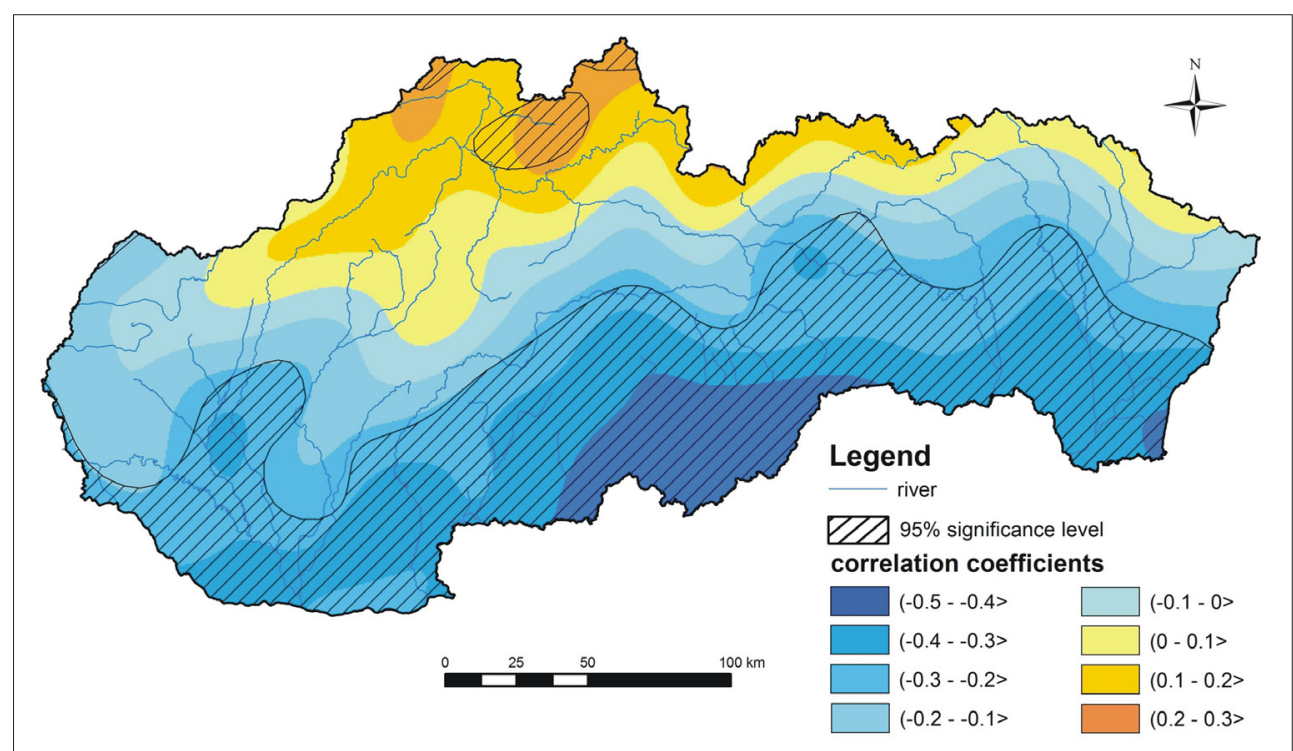

Fig. 6: Spatial distribution of the correlation coefficients between the Hurrell winter oscillation index and the winter precipitation totals in Slovakia in period 1901-2010 
the correlations do not reach high values and only less than $2 \%$ of the winter precipitation variance in region 3 can be explained by the influence of the NAO. This zone with low positive correlation values is neighbour to a transition zone, characterised by low negative correlation coefficients. This zone consists of the region of Záhorie and a part of middle Považie (region 1), upper Nitra, upper and middle Hron river basin (region 4 and 6) and the northern part of eastern Slovakia (region 7 and 8). The closest relation between the NAO and the winter precipitation totals was detected in the most southern regions of Slovakia, more exactly at Podunajská and Východoslovenská nižina (region 2 and 9) and in the southern part of central Slovakia (region 5). In southern regions, some $17 \%$ of the winter precipitation variance can be explained by the NAO impact. The significant results were only obtained in these last-mentioned regions with the strongest correlation of winter precipitation and the NAO. The exception is region 6 , which is located in the transition zone (correlation coefficient is equal to - 0.26) and the correlation in this area is also significant.

The spatial distribution generated from this generalised method was replicated by the analysis of the relations at the higher resolution level. The zonal configuration of the NAO impact on the winter precipitation totals is displayed in the final map, with higher spatial resolution (Fig. 6). Similar to the generalised level, the Orava and Kysuce region is the only one which records positive correlation coefficients, but this zone continues as a narrow belt through the High Tatra's ridge and along northern country border, almost to the SlovakiaUkraine border. To the south, a transition zone with lower values of correlation coefficients is located in a latitudinal direction. The highest, but negative correlation is recorded in the region of Juhoslovenská kotlina, where correlations up to -0.5 were identified (Tab. 2). A relatively higher negative correlation was also recorded in the Spiš region. This region has a special orographical position, because it is completely surrounded by mountains. The annual precipitation total is relatively low here, because of a multiplied shadow effect. A similar phenomenon of a higher negative correlation appears in the surroundings of Galanta. This region is located in the rain shadow of the mountains neighbouring this area from the west and north, which influences the prevailing flow from the west and northwest and brings less precipitation into this region.

Not all correlations are statistically significant at the significance level $\alpha=0.05$. The statistically significant results were identified mostly in the southern half of Slovakia, with negative values of the correlation coefficient. In the small areas in the most northern region (Orava and Kysuce region), the highest positive (and statistically significant) correlation was recorded. The relationship between the NAO and the winter precipitation totals in the area with statistically significant correlation of the winter precipitation variance can explain at most $25 \%$ in the region of highest negative correlation, and $7.3 \%$ in the region of the most positive correlation. Without doubt, this distribution of statistical relationships between the NAO Index and winter precipitation refers better to the real conditions in landscape situations than the results obtained from the generalised way, because the precipitation regions cover quite large areas and therefore local differences within smaller regions are smoothed.

\begin{tabular}{|l|c|c|c|}
\hline \multicolumn{1}{|c|}{ Rain gauge station } & Latitude & Longitude & Correlation coefficient \\
\hline Cinobaňa & $48^{\circ} 26^{\prime} 45^{\prime \prime}$ & $19^{\circ} 39^{\prime} 20^{\prime \prime}$ & -0.42 \\
\hline Dolné Plachtince & $48^{\circ} 12^{\prime} 24^{\prime \prime}$ & $19^{\circ} 19^{\prime} 12^{\prime \prime}$ & -0.41 \\
\hline Hnúšţa & $48^{\circ} 35^{\prime} 3^{\prime \prime}$ & $19^{\circ} 56^{\prime} 43^{\prime \prime}$ & -0.40 \\
\hline Hrachovo & $48^{\circ} 27^{\prime} 46^{\prime \prime}$ & $19^{\circ} 57^{\prime \prime} 6^{\prime \prime}$ & -0.40 \\
\hline Jelšava & $48^{\circ} 37^{\prime} 50^{\prime \prime}$ & $20^{\circ} 14^{\prime} 20^{\prime \prime}$ & -0.42 \\
\hline Královský Chlmec & $48^{\circ} 25^{\prime} 15^{\prime \prime}$ & $21^{\circ} 58^{\prime} 46^{\prime \prime}$ & -0.40 \\
\hline Lučenec & $48^{\circ} 19^{\prime} 46^{\prime \prime}$ & $19^{\circ} 39^{\prime} 16^{\prime \prime}$ & -0.50 \\
\hline Poltár & $48^{\circ} 26^{\prime} 4^{\prime \prime}$ & $19^{\circ} 47^{\prime} 59^{\prime \prime}$ & -0.42 \\
\hline Ratková & $48^{\circ} 35^{\prime} 32^{\prime \prime}$ & $20^{\circ} 6^{\prime} 0^{\prime \prime}$ & -0.42 \\
\hline Rimavská Sobota & $48^{\circ} 22^{\prime} 26^{\prime \prime}$ & $20^{\circ} 0^{\prime} 38^{\prime \prime}$ & -0.40 \\
\hline Slanec & $48^{\circ} 38^{\prime}$ & $21^{\circ} 29^{\prime}$ & -0.44 \\
\hline Tornala & $48^{\circ} 25^{\prime} 15^{\prime \prime}$ & $20^{\circ} 19^{\prime} 46^{\prime \prime}$ & -0.45 \\
\hline
\end{tabular}

Tab. 2: The most negative correlation coefficients (at significance level $\alpha=0.05$ ) between the Hurrel winter NAO Index and the winter precipitation totals in Slovakia 
A relatively high gradient of correlation coefficients in a north-south direction was found, considering such a 'narrow' territory as that of Slovakia. This zonal configuration can be explained mostly by the orography of the area, where the barrier effect of mountains (rain shadow effects) influences the precipitation distribution. The prevailing air-flow over the study area is from a northwestern and western direction. The prevailing air flow and the orography of the Carpathian belt cause multiple rain shadows, especially in the Juhoslovenská kotlina, but also in the lowland regions (Východoslovenská and Podunajská nížina) and in the region of Spiš. In these regions, in particular, the highest negative correlations are detected. This indicates that during the positive oscillation phase, when most storms move into Scandinavia, then the western, northwestern and northern cyclonic situations have a dominant role in the spatial distribution of precipitation in Slovakia. The precipitation connected with these situations falls mainly on the windward northwestern and northern parts of the Carpathians and the precipitation totals decrease southward and southeastward.

In other words, the more often that precipitation comes from the northwest and the north, lower precipitation totals occur in the south of Slovakia. Vice versa, during the negative oscillation phase, when storms from the Atlantic move towards the Mediterranean region, then southwestern, southern and southeastern synoptic situations bring more precipitation to the regions of Slovakia, which are situated in the rain shadow during the positive phase of oscillation. The distribution of precipitation during these situations was described in Ballon et al. (1964), Brádka (1972) and Šamaj et al. (1985).

This hypothesis of the influence of the Carpathian belt barrier effect on the final impact of the NAO on the precipitation totals is supported by the fact that no dependence of the correlation coefficients on altitude was detected. The positive NAO - precipitation correlation is not reached even in the high mountains located in central part of Slovakia, but in lower mountains situated in northern part of the Carpathians as well.

The precipitation conditions in the southern part of Slovakia are more dependent on southern air flows, and an explanation could be the impact of other circulation modes. Its influence on the precipitation totals is supposed especially in the lowland regions (Podunajská nížina, Východoslovenská nížina) and in the region of Juhoslovenská kotlina. These regions are very important from an agricultural viewpoint, where precipitation has a major importance. Therefore, further research should be oriented to understanding these relations.

\section{Discussion and conclusions}

The impact of the North Atlantic Oscillation on climatic elements is very complicated. It results from the complexity of the phenomenon itself, which is caused by internal atmospheric processes within oscillation, which influence each other, and unpredictable (random) changes in the NAO phases which are a product of this co-influence (Hurrell, 2011). The assessment of the NAO impact on the amount, time and spatial distribution of precipitation in Slovakia is interesting due to the location of the country within Europe, especially since Slovakia is situated in the region where two different oscillation influences (the North Atlantic and the Mediterranean Oscillation) probably collide.

Our results agree with those of Casty et al. (2005), who also inferred the possible influence of other circulation modes on precipitation in Alpine regions. However, our study area is not in the Alpine region, but it is very close to it and the Carpathians produce similar barrier effect to the Alps. Therefore similar phenomena of the influence of circulation modes can occur in the Carpathians region. Domonkos and Tar (2003) depicted the fact that a large portion of precipitation in Hungary falls from Mediterranean or quasiMediterranean cyclones. This fact is most important for the southern parts of Slovakia close to the borders with Hungary, where similar negative correlations are identified. This finding indicates the needs for further research regarding the influence of other circulation modes (especially of the Mediterranean Oscillation) and the relationships between them.

The results presented here are not in accordance with the results published by Beranová, Huth (2008). One of their conclusions was that the impact of the NAO on precipitation in Central Europe was insignificant. The difference in these results is probably caused by the fact that those authors selected only the climatological station Hurbanovo as representative for the whole of Slovakia. More detailed spatial analysis was not done, despite the fact that the country is very heterogeneous from an orographic viewpoint. In addition, the results of our analyses confirm the conclusions of Pishvaei (2003), who used relatively detailed spatial generalisation with five precipitation regions and two representative stations in each region, although the time period used was shorter than that in our study.

In addition, our results can be interpreted as the impact of orography on precipitation conditions. The regions of Slovakia with the highest negative correlations are situated in the multiple rain shadows of the Carpathians. The orographic effects prevent the occurrence of higher precipitation caused by western, northwestern and 
northern cyclonic situations, which prevail during the positive NAO phase. The southwestern, southern and southeastern cyclonic situations are more important during the negative oscillation phase, when higher precipitation totals are recorded in the southern parts of Slovakia. Our hypothesis corresponds to Cherry et al. (2000). They present the same explanation of the NAO impact in Scandinavia. This hypothesis is also confirmed by Doležalová (2007): in her analyses, a significant oscillation impact was only shown in the region of Moravia and Silesia, and it was probably caused by the orographic effect of the neighbouring Carpathians. The hypothesis is also in accordance with the results by Domonkos and Tar (2003), who demonstrated that the negative correlation between the NAO and winter precipitation in Hungary is caused by the specific orographic conditions of the country. The final oscillation impact on the precipitation in the south of Slovakia is probably caused by the barrier effect of the Carpathian Mountains.

Our results detected the impact of the North Atlantic Oscillation on the winter precipitation totals in Slovakia. The zonal distribution of the final correlation coefficients between the Hurrell winter oscillation index NAOI-H and the winter precipitation totals was demonstrated for the territory of Slovakia, for both of the spatial resolution levels that were used. A positive correlation was obtained only in the region of Orava and Kysuce, with low, but significant values. Southward, the correlation coefficients change into negative values, which are the lowest and most significant in the region of Juhoslovenská kotlina and the lowland regions (Podunajská nížina, Východoslovenská nížina). This distribution can be explained by the barrier effect of the Carpathian Mountains. It can also be expected that the impact of other circulation modes is important for these lastmentioned regions.

\section{Acknowledgments}

The article was prepared with the support of grant UK/44/2013 and with the support of the Slovak Research and Development Agency in the frame of the contract No. APVV 0303-11.

\section{References:}

AHRENS, C. D. (2007): Essentials of Meteorology: An Invitation to the Atmosphere (5 ${ }^{\text {th }}$ Edition) Brooks Cole, 504 pp.

BALLON, L., FORGÁČ, P., MOLNÁR, F. (1964): Počasie na území Slovenska za typických poveternostných situácií. HMÚ, Praha, 30 pp.

BARNSTON, A. G., LIVEZEY, R. E. (1987): Classification, Seasonality and Persistence of Low-Frequency Atmospheric Circulation Patterns. Monthly Weather Review, Vol. 115, No. 6, p. 1083-1126.

BARRY, R. G., CHORLEY, R. J. (2003): Atmosphere, weather and climate. London, Butler and Tanler Ltd., 368 pp.

BERANOVÁ, R., HUTH, R. (2008): Time variations of the effects of circulation variability modes on European temperature and precipitation in winter. International Journal of Climatology, Vol. 28, No. 2, p. 139-158.

BEDNORZ, E. (2004): Snow cover in Eastern Europe in relation to temperature, precipitation and circulation. International Journal of Climatology, Vol. 24, No. 5, p. 591-601.

BODRI, L., CERMAK, V., KRESL, M. (2005): Trends in precipitation variability: Prague (the Czech Republic). Climatic Change, Vol. 72, No. 1-2, p. 151-170.

BRÁDKA, J. (1972): Srážky na území ČSSR při jednotlivých typech povětrnostní situace. Sborník prací HMÚ 18. Praha, p. 8-62.

BRÁZDIL, R., CHROMÁ, K., DOBROVOLNÝ, P., TOLASZ, R. (2009): Climate fluctuations in the Czech Republic during the period 1961-2005. International Journal of Climatology, Vol. 29, No. 2, p. 223-242.

BRÁZDIL, R., ZAHRADNÍČEK, P., PIŠOFT, P., ŠTĚPÁNEK, P., BĚLÍNOVÁ, M., DOBROVOLNÝ, P. (2012): Temperature and precipitation fluctuations in the Czech Republic during the period of instrumental measurements. Theoretical and Applied Climatology, Vol. 110, No. 1-2, p. 17-34.

CASTY, C., WANNER, H., LUTERBACHER, J., ESPER, J., BÖHM, R. (2005): Temperature and precipitation variability in the European Alps since 1500. International Journal of Climatology, Vol. 25, No. 14, p. 1855-1880.

CHERRY, J., CULLEN, H., VISBECK, M. (2000): Impacts of the NAO on the Energy Sector: the Norwegian example. Paper presented at the AGU Chapman Conference „The North Atlantic Oscillation“, Galicia 28.11.-1.12.2000. [online]. [cit. 20.10.2012]. Available at URL: http://xtide.ldeo.columbia.edu/ visbeck/nao/poster/Cherry.pdf

CICCARELLI, N., VON HARDENBERG, J., PROVENZALE, A., RONCHI, C., VARGIU, A., PELOSINI, R. (2008): Climate variability in north-western Italy during the second half of the 20th century. Global and Planetary Change, Vol. 63, No. 2-3, p. 185-195.

DOLEŽALOVÁ, M. (2007): Projevy Severoatlantské oscilace v časové variabilitě teploty vzduchu a srážek na území České republiky. Meteorologický Časopis, Vol. 10, No. 2, p. 91-99. 
DOMONKOS, P., TAR, K. (2003): Long-term changes in observed temperature and precipitation series 1901-1998 from Hungary and their relations to larger scale changes. Theoretical and Applied Climatology, Vol. 75, No. 3-4, p. 131-147.

GIMENO, I., DE LA TORRE, L., NIETO, R., ANEL, J. A. (2005): North Atlantic Oscillation (NAO) and precipitation in Galicia (Spain). Atmósfera, Vol. 18, No. 1, p. 25-32.

HURRELL, J. W. (1995): Decadal Trends in the North Atlantic Oscillation: Regional Temperatures and Precipitation. Science, Vol. 269, No. 5224, p. 676-679.

HURRELL, J. W. (1996): Influence of variations in extratropical wintertime teleconnections on Northern Hemisphere temperature. Geophysical Research Letters, Vol. 23, No. 6, p. 655-668.

HURRELL, J. (2001): North Atlantic Oscillation. Encyclopaedia of Ocean Sciences, Vol. 4, p. 1904-1911.

HURRELL, J. W., KUSHNIR, Y., OTTERSEN, G., VISBECK, M. [eds.] (2003): The North Atlantic Oscillation: Climatic Significance and Environmental Impact, Geophysical Monograph Series, No. 134, 279 pp.

HURRELL, J. W. (2011): Introduction to NAO Indices. [online] [cit. 05.10.2011]. Available at URL: http://www.cgd.ucar.edu/ cas/jhurrell/naointro.html

HURRELL, J. W. (2012). NAO Index Data provided by the Climate Analysis Section, NCAR. [online] [cit. 02.12.2011]. Available at URL: http://climatedataguide.ucar.edu/guidance/hurrell-north-atlantic-oscillation-nao-index-station-based

HURRELL, J. W. (2013): The Climate Data Guide: Hurrell North Atlantic Oscillation (NAO) Index (station-based). [online] [cit. 11.11.2013]. Available at URL: https://climatedataguide.ucar.edu/climate-data/hurrell-north-atlantic-oscillation-naoindex-station-based

JÓNDÓTTIR, J. F., UVO, C. B. (2009): Long-term variability in precipitation and streamflow in Iceland and relations to atmospheric circulation. International Journal of Climatology, Vol. 29, No. 10, p. 1369-1380.

LAMB, P. J., PEPPLER, R. A. (1987): North Atlantic Oscillation: Concept and an Application. Bulletin American Meteorological Society, Vol. 68, No. 10, p. 1218-1225.

MATTI, C., PAULING, A., KÜTTEL, M., WANNER, H. (2009): Winter precipitation trends for two selected European regions over the last 500 years and their possible dynamic background. Theoretical and Applied Climatology, Vol. 95, No. 1-2, p. $9-26$.

MITCHELL, T. (2002): North Atlantic Oscillation (NAO) Index. [online] [cit. 29.10.2012]. Available at URL: http://jisao. washington.edu/data_sets/nao/

MURPHY, S. J., WASHINGTON, R. (2001): United Kingdom and Ireland precipitation variability and the North Atlantic sealevel pressure field. International Journal of Climatology, Vol. 21, No. 8, p. 939-959.

NIEDZWIEDZ, T., TWARDOSZ, R., WALANUS, A. (2009): Long-term variability of precipitation series in east central Europe in relation to circulation patterns. Theoretical and Applied Climatology, Vol. 98, No. 3-4, p. 337-350.

OLIVER, J. E. [ed.] (2008): Encyclopedia of world climatology. Cornwall, Springer, 854 pp.

OSBORN, T. J., BRIFFA, K. R., TETT, S. F. B., JONES, P. D., TRIGO, R. M. (1999): Evaluation of the North Atlantic Oscillation as simulated by a coupled climate model. Climate Dynamics [online], Vol. 15, No. 9, p. 685-702. [cit. 20.01.2012]. Available at URL: http://www.springerlink.com/content/h1lj48bd98w6tln5/fulltext.pdf

PEKÁROVÁ, P., MIKLÁNEK, P., PEKÁR, J. (2010): Možnosti dlhodobej predikcie prietokov slovenských tokov na základe indexu Severoatlantickej oscilácie NAOI. Acta Hydrologica Slovaca, Vol. 11, No. 2, p. 282-290.

PISHVAEI, M. R. (2003): Study of precipitation time series in Slovakia and Iran. Bratislava, Univerzita Komenského, 256 pp.

QUERALT, S., HERNÁNDEZ, E., BARRIOPEDRO, D., GALLEGO, D., RIBERA, P., CASANOVA, C. (2009): North Atlantic Oscillation influence and weather types associated with winter total and extreme precipitation events in Spain. Atmospheric Research, Vol. 94, No. 4, p. 675-683.

SACHS, L., HEDDERICH, J. (1972): Angewandte Statistik. Heidelberg, Springer, 902 pp.

TRIGO, R. M., POZO-VÁZQUEZ, D., OSBORN, T. J., CASTRO-DIÉZ, Y., GÁMIZ-FORTIS, S., ESTEBAN-PARRA, M. J. (2004): North Atlantic Oscillation influence on precipitation, river flow and water resources in the Iberian peninsula. International Journal of Climatology, Vol. 24, No. 8, p. 925-944.

ŠAMAJ, F., VALOVIČ, Š., BRÁZDIL, R. (1985): Denné úhrny zrážok s mimoriadnou výdatnostou v ČSSR v období 1901-1980. Zborník prác SHMÚ, 24. Alfa, Bratislava. p. 9-113.

ŠAMAJ, F., VALOVIČ, Š. (1982): Priestorové úhrny zrážok na Slovensku (1881-1980). Meteorologické zprávy, 35, p. $108-112$.

TRIGO, R. M., ZEZERE, J. L., RODRIGUES, M. L., TRIGO, I. F. (2005): The Influence of the North Atlantic Oscillation on Rainfall Triggering of Landslides near Lisbon. Natural Hazards, Vol. 36, No. 3, p. 331-354. 
TWARDOSZ, R., LUPIKASZA, E., NIEDWIEDZ, T., WALANUS, A. (2011): Long-term variability of occurrence of precipitation forms in winter in Krakow, Poland. Climatic Change, Vol. 113, No. 3-4, p. 623-638.

VISBECK, M. H., HURRELL, J. W., POLVANI, L., CULLEN, H. M. (2001): The North Atlantic Oscillation: Past, present and future. PNAS [online], Vol. 98, No. 23, p. 12876-12877. [cit. 20.10.2012]. Available at URL: http://www.pnas.org/ content/98/23/12876.full.pdf+html

\section{Authors' addresses:}

Mgr. Lívia LABUDOVÁ

Department of Physical Geography and Geoecology, Faculty of Natural Sciences

Comenius University in Bratislava

Mlynská dolina, 84215 Bratislava, Slovakia

e-mail:leskoval@fns.uniba.sk

RNDr. Pavel ŠŤASTNÝ, CSc.

Department of Climatological Service, Slovak hydrometeorological institute

Jeséniova 17, 83315 Bratislava, Slovakia

e-mail:pavel.stastny@shmu.sk

Doc. RNDr. Milan TRIZNA, Ph.D.

Department of Physical Geography and Geoecology, Faculty of Natural Sciences

Comenius University in Bratislava

Mlynská dolina, 84215 Bratislava, Slovakia

e-mail:trizna@fns.uniba.sk

Initial submission 8 November 2012, final acceptance 2 December 2013

Please cite this article as:

LABUDOVÁ, L., ŠŤASTNÝ, P., TRIZNA, M. (2013): The North Atlantic Oscillation and winter precipitation totals in Slovakia. Moravian Geographical Reports, Vol. 21, No. 4, p. 38-49, DOI: 10.2478/mgr-2013-0019. 